\title{
Non-Governmental Control in the Sphere of National Security of Ukraine
}

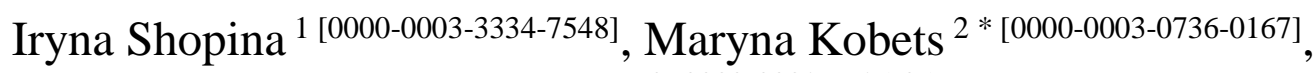 \\ Serhii Tarasov 3 [0000-0002-7625-0597] \\ ${ }^{1}$ Lviv State University of Internal Affairs, Lviv, Ukraine \\ ${ }^{2}$ State Research Institute of the Ministry of Internal Affairs of Ukraine, Kiev, Ukraine \\ ${ }^{3}$ Central Research Institute of the Armed Forces of Ukraine, Kiev, Ukraine \\ *kobetsmp@gmail.com
}

\begin{abstract}
The article is devoted to the content and concepts of democratic civilian control and non-government control in the sphere of national security. The process of the emergence of democratic civilian control in the field of national security in Ukraine is considered. The international obligations of Ukraine in the framework of ensuring democratic civilian control over the security sector have been systematized. The features of national legal acts have been clarified. In this work a distinction is made between the terms "civil control" and " non-government control". Emphasized that the legislator, relying on international standards of democratic citizen control, has applied English terms in national legislation in a superficial manner. Proved that control by civil society, has the meaning of «civilian control» embedded in international norms, can be defined as «non-government control», laying down one of the main principles transparency, accessibility and accountability by civil society. It has been determined that civil society should be aimed at promoting the effective functioning of the security sector bodies and the fulfilment of their functions, and at strengthening the national security of Ukraine, although it may be of a recommendatory nature. It is concluded that democratic civilian control over the national security sector should be considered from the perspective of different components - social and government.
\end{abstract}

Keywords: non-governmental control, national security, democratic civilian control, civilian control, civilian oversight.

\section{INTRODUCTION}

After gaining independence, Ukraine chose the democratic priorities of its development, and therefore the national security policy was radically changed. Its goal was to protect national interests from external and internal threats, based on the principles and norms of international law. Ukraine has become an essential factor in ensuring regional security and is considered by the world community as a subject of confrontation between various world centers of power.

Ukraine has undergone some democratic transformational processes, has chosen a European foreign policy vector, and has become an active participant in international relations. These factors have contributed to the establishment of effective democratic civilian control in the area of national security, which should become a priority mechanism for the implementation of the principles of democratization, based on the experience of EU and NATO member States.

According to international independent experts, Ukraine has not yet established a full-fledged system of democratic civilian control, with a clear delineation of responsibility between State authorities, civilians and the military. Therefore, the system of democratic civilian control over the state's security sector cannot be considered satisfactory, since one of its basic principles the responsibility of civilians for the effectiveness of the State's defense sector - is violated [1, 2]. It should also be mentioned that national security and democratic civilian control regulations contain a lot of contradictions that require scientific approach.

At present, scientists and practitioners do not fully understand the essence of democratic civic control, that is why the substitution of basic concepts is often observed. For example, "state control" is represented as 
"democratic civil control" and vice versa [3] the concepts of "civil control", "non-governmental control" and "public control" [4] are not differentiated. Such free use of these concepts in lawmaking contradicts its basic principles [5], such as scientific validation [6-8] and systematic approach.

The purpose of the article is to study the content and concepts of democratic civil control and nongovernmental control in the sphere of national security based on international standards, as well as to analyze the implementation feature of non-governmental control over the national security sector in Ukraine.

\section{MATERIALS AND METHODS}

The main materials that became the basis for this study are international legal acts: Universal Declaration of Human Rights (1948) [9], International Covenant on Civil and Political Rights (1966) [10], International Convention on the Elimination of All Forms of Racial Discrimination (1965) [11], Convention against Torture and Other Cruel, Inhuman or Degrading Treatment or Punishment (1984 p), Convention for the Protection of Human Rights and Fundamental Freedoms (1950) (ratified in 1997) [12], Charter on a Distinctive Partnership between the North Atlantic Treaty Organization and Ukraine (1997) [13], NATO-Ukraine Action Plan, adopted by the NATO-Ukraine Commission in 2002 [14], NATO-Ukraine Annual Target Plans [1517] etc. The study is predominantly based on the work of leading experts in the field of national security, democratic civilian control and public oversight of the security sector. [18].

To achieve the objective of the study and to sustain the comprehensive understanding of the materials, the authors used a synthesis of various scientific methods. Of particular importance are the following methods: system analysis, dialectics and synthesis methods. These approaches provided with an idea of legal norms in the field of national security, democratic civilian control and non-government control over the security sector both in the EU and NATO member states and in Ukraine. The formal-logical method and structural analysis were useful for identifying weaknesses in the legal regulation of the implementation of non-government control over the national security sector in Ukraine, as well as issues of implementation of international standards and experience of the EU and NATO member states.

\section{RESULTS}

Democratic civilian control, as an instrument of society monitoring of State bodies' and officials' activities, emerged after the Second World War as a response of democratic political institutions to the danger of an unjustified strengthening of the role of military organizations. Such an instrument included the establishment of mechanisms to influence the military organization, to ensure accountability and control of the society through the democratically elected institutions [19, p. 677-678].

Conceptually founded as early as the middle of the last century, democratic civilian control was implemented in national legislation only in 2003 by the Law of Ukraine of 19.06.2003 N 975-IV «On democratic civilian control over the military organization and law enforcement agencies».

It should be noted that Ukraine's international obligations to establish democratic civilian control over the security sector accrued much earlier. Table 1 below shows the main documents ratified by Ukraine related to the organization and maintenance of democratic civilian control over the security sector.

Table 1. Ukraine's international obligations within the framework of democratic civilian control

\begin{tabular}{|l|l|}
\hline \multicolumn{1}{|c|}{$\begin{array}{c}\text { Ukraine's international } \\
\text { obligations }\end{array}$} & \multicolumn{1}{|c|}{ Documents providing for obligations } \\
\hline $\begin{array}{l}\text { in the framework of membership } \\
\text { and cooperation with the United } \\
\text { Nations }\end{array}$ & $\begin{array}{l}\text { Universal Declaration of Human Rights (1948) [9], } \\
\text { International Covenant on Civil and Political Rights (1966) [10], } \\
\text { International Convention on the Elimination of All Forms of Racial } \\
\text { Discrimination (1965) [11], } \\
\text { Convention against Torture and Other Cruel, Inhuman or Degrading } \\
\text { Treatment or Punishment (1984). }\end{array}$ \\
\hline $\begin{array}{l}\text { in the framework of membership } \\
\text { and } \begin{array}{l}\text { Organization for Security and Co- } \\
\text { operation in Europe }\end{array}\end{array}$ & $\begin{array}{l}\text { Document of the Copenhagen meeting of the Conference on the human } \\
\text { dimension of the Conference on Security and Cooperation in Europe } \\
\text { (1990) [20], }\end{array}$ \\
\hline
\end{tabular}




\begin{tabular}{|c|c|}
\hline & $\begin{array}{l}\text { Code of Conduct on Politico-Military Aspects of Security (1994) «Towards } \\
\text { A Genuine Partnership in a New Era», } \\
\text { Code of Conduct for Staff/Mission Members (2003). }\end{array}$ \\
\hline $\begin{array}{l}\text { in the framework of membership } \\
\text { and cooperation with the Council of } \\
\text { Europe }\end{array}$ & $\begin{array}{l}\text { Convention for the Protection of Human Rights and Fundamental Freedoms } \\
\text { (1950) (ratified in 1997) [12] }\end{array}$ \\
\hline $\begin{array}{l}\text { in the framework of cooperation } \\
\text { with NATO }\end{array}$ & $\begin{array}{l}\text { Charter on a Distinctive Partnership between the North Atlantic Treaty } \\
\text { Organization and Ukraine (1997) [13], } \\
\text { NATO-Ukraine Action Plan, adopted by the NATO-Ukraine Commission in } \\
2002 \text { [14], } \\
\text { NATO-Ukraine Annual Target Plans [15-17], } \\
\text { The NATO Partnership for Peace Program and Partnership for Peace: } \\
\text { Framework Document (1994), } \\
\text { Declaration to Complement the Charter on a Distinctive Partnership } \\
\text { between the North Atlantic Treaty Organization and Ukraine, signed on } 9 \text { July } \\
1997\end{array}$ \\
\hline $\begin{array}{l}\text { in the framework of cooperation } \\
\text { with EU }\end{array}$ & $\begin{array}{l}\text { EU Action plan on justice and home affairs in Ukraine (Text approved by the } \\
\text { Council on } 10 \text { December 2001) [21], } \\
\text { EU Action plan on justice and home affairs in Ukraine (2003) [22], } \\
\text { EU Action plan on justice and home affairs in Ukraine (2005) [23], } \\
\text { European Committee for the Prevention of Torture Resolution (2007), } \\
\text { EU-Ukraine Association Agenda to prepare and facilitate the implementation } \\
\text { of the Association Agreement [24]. }\end{array}$ \\
\hline
\end{tabular}

The legal analysis of Ukraine's obligations within the framework of ensuring democratic civilian control over the security sector [25] made it possible to conditionally divide them according to the scope of application into general (covering the entire security policy) and special (directly related to a separate area of national security). In addition, the analysis highlighted the main principles in the area of national security, namely, the rule of law, human rights, transparency, accountability to the relevant State bodies and civil society, and depoliticization.

The principles of transparency and accountability are implemented in accordance with the requirements of the information legislation of Ukraine, in particular the Law of Ukraine «On Access to Public Information» [26]. For example, in response to the requirements of articles 1921 of the above-mentioned Law, the security and defense sector of Ukraine is actively involved in the information request compliance process [27]. The demand for this form of non-government control is evidenced by the dynamics of its use. The chart below demonstrates the upward trend of applying of non-government control (Figure 1).

The bar-chart demonstrate the upward trend of requests for public information access, received by the Ukrainian Ministry of Defence in 2019 and 2020 with. It can be seen that total amount of requests has increased from 1280 in 2019 to 1700 in 2020 . Looking in closer detail at the chart, it can been observed the significant growth of requests from natural persons (from 1032 to 1401) as well as positive addition by other criteria.

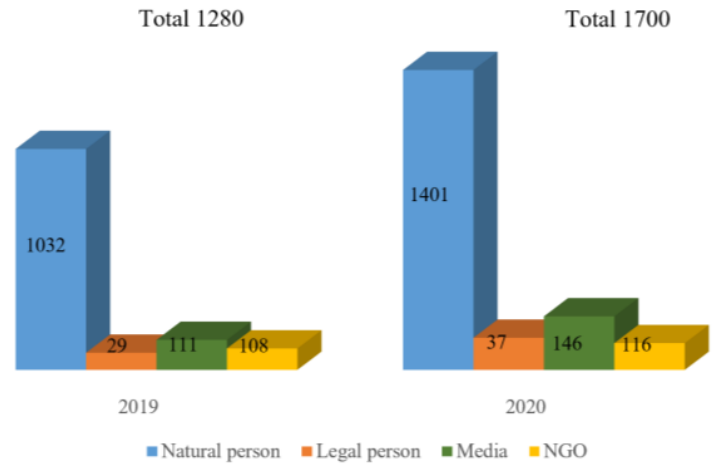

Figure 1 Dynamics of the number of requests for public information access received by the Ukrainian Ministry of Defense in 2019-2020.

A key feature of national security is secrecy and concealment, so the introduction of independent oversight by civil society must be a particular tool to prevent any translation of military strength into political 
advantage. Thanks to the Law of Ukraine «On Democratic Civilian Control over Military Organization and Law Enforcement Bodies " for the first time Ukrainian citizens were given the opportunity to control the national security sector. The disadvantage of these norms was their application in the declarative manner, since direct monitoring must be conducted by means of an appeal to the Human Rights Commissioner of the Verkhovna Rada and his representative for the protection of the rights of military personnel, or to another State body in the manner, specified by special legislation, or by participation in public organizations.

In 2018, the national security legislation was updated, namely the Law of Ukraine «On National Security of Ukraine» has been adopted. This Act lays down the basic rules of democratic civil control, clarifies the concept of civil control, [24] however, the level of detail of legal regulation has decreased.

Article 4 of the Law «On National Security of Ukraine» updated the concept of «democratic civil control» by control from the President of Ukraine, the Verkhovna Rada of Ukraine, the National Security and Defence Council of Ukraine, the Cabinet of Ministers of Ukraine, Executive and local government bodies, as well as judicial control and non-government oversight. However, the terms used by the legislator needed to be clarified.

Usually in global best practices, the English term «civilian» denotes a special mechanism for strategic management in the military sphere, which is done by State bodies that are not part of a military organization. In another case («civil» is more often used as «civil society») when it comes to control by society and its nongovernment institutions.

In our opinion, the legislator, relying on international standards of democratic citizen control, has not defined the actual content of the English terms and consequently has applied them in national legislation in a superficial manner. This is also evidenced by the fact that control from the President of Ukraine, the Verkhovna Rada of Ukraine, the National Security and Defence Council of Ukraine, the Cabinet of Ministers of Ukraine, Executive and local government bodies, as well as judicial control are judicial control are classified as "civilian control", although obviously they should be defined as government control or control from representative bodies. At the same time, control by civil society, has the meaning of «civilian control» embedded in international norms, can be defined as «non-government control», laying down one of the main principles - transparency, accessibility and accountability by civil society.

\section{DISCUSSION}

The Law of Ukraine "On the National Security of Ukraine" dated 15.08.2020 No. 2469-VIII [23] defined the concept of "democratic civilian control". Article 4 states that the system of civilian control also includes non-government monitoring (control). Based on the definition of lawmakers, " non-government control" is an integral part of "civilian control", which is methodologically incorrect and rather controversial. Most scientists (A. Zabralova, A. Selivanova, V. Pylin, S. Pylin, A. Klinshans, S. Morozov, L. Nalivaiko, A. Savchenko) noted that, on the contrary, civilian control is a component of non-government control and literately represents the control of individual citizens over the activities of state bodies and officials.

Non-government control as control by society is a more general concept than civilian control, which can be considered as part of non-government control aimed to control a specific sector of society - the public sector within the framework of state and civil society interaction. The concept of "non-government" (social, common) comes from a certain set of people, united by territory, culture, religion etc; at the same time the concept of "civilian" is a derivative tracing of the Greek word polit3s ("citizen"), derived from the Greek polis ("city") and means "town dweller." In this regard, the subject of non-government control is often devoid of personification and represents a kind of community of people driven by public and collective interests; the concept of "civilian" implies the maximum personification of the subject.

Meanwhile, I. Khraban says that the term "civilian control over the army" is a literal translation from English, which is already used in the national scientific literature. However, the scientist defined the meaning of this term as a complex mechanism of management (control) over the army by the people both through state institutions and through independent associations. And the main purpose of civilian control is the compliance of the armed forces with the needs and interests of society. Considering " non-government control" (F. Schmitter, D. Lloyd, M. Prelo, A. Bogucharsky, M. Howard) they represent the instrument to establish the rule of law and a democratic state, which is based on balancing the interests of society and government.

It is important to note that in the National Security Law the term "oversight", which, although synonymous with the word "control," does not include the concept of "improvement and development". Thus, by law, civil society must monitor (oversight) the national security sector, but not influence its improvement, and this, in turn, does not correlate with international standards of democratic civil control.

It has now become necessary to make a clear distinction between the above-mentioned concepts, as their free use in law-making contradicts its basic principles of scientific sufficiency and consistency. 


\section{CONCLUSIONS}

According to the Law on National Security, democratic civilian control in the field of national security is a complex of legal, organizational, informational, personnel and other measures to ensure the rule of law, legality, accountability, transparency of the security and defense sector and other bodies whose activities are related to legal restrictions human rights and freedoms, promotion of their effective activities and performance of the functions assigned to them, strengthening of the national security of Ukraine.

Non-government control in the field of national security control measures carried out by civil society institutions to ensure the rule of law, accountability, transparency of the security sector and other bodies whose activities are related to national security. Civil society should be aimed at promoting the effective functioning of the security sector bodies and the fulfilment of their functions, and at strengthening the national security of Ukraine, although it may be of a recommendatory nature.

Democratic civilian control over the national security sector should be considered from the perspective of different components - social and government.

\section{REFERENCES}

[1] Vychalkivska, Yu. S. "Ukraine's responsibility for the establishment of democratic civil survey over the power and special structures of the state", Investments: practice and experience, vol. 2. Mykolaiv, DKS Cente, 2018, pp. 112-118.

[2] Kovalchuk, T.I. Korystin, O.Y. and Sviridyuk, N.P. (2019), "Hybrid threats in the civil security sector in Ukraine", Problems of Legality, vol. 147, pp. 163-175, DOI: $\quad 10.21564 / 2414-$ 990x.147.180550

[3] Chornyi, V.S. "Features of democratic civilian control of the military sphere of ukrainian society at the modern stage", Social development \& Security, vol. 3(5), Kyiv, non-governmental organization "Ukrainian scientific community", 2018, pp. 3-13. DOI: 10.5281/zenodo.1296092.

[4] Kobets, M. P. "Actual problems of development of military law”, in: I. V. Tolok (Ed.), Science of law of national security and military law in the context of reforming the education and science system of Ukraine, Kyiv, Military Institute of Taras Shevchenko National University of Kyiv, 2021, pp. 26-27.

[5] Li-juan Wei and Cong-ying Liu (2011), "On Basic Principles in Contrastive Analysis", IJEME, vol. 1, no. 6, pp. 57-62, DOI: 10.5815/ijeme.2011.06.09
[6] Prasenjit, Banerjee and Anirban, Sarkar (2018), "Quality Evaluation of Component-Based Software: An Empirical Approach", International Journal of Intelligent Systems and Applications, vol. 10, no. 12, pp. 80-91, DOI: $10.5815 /$ ijisa.2018.12.08

[7] Folasade, O. Isinkaye and Yetunde, O. Folajimi (2018), "Experimental Validation of Contextual Variables for Research Resources Recommender System", International Journal of Intelligent Systems and Applications, vol. 10, no. 4, pp. 50-57, DOI: $10.5815 /$ ijisa.2018.04.06

[8] Kumar Rajnish (2014), "Theoretical Validation of Inheritance Metrics for Object-Oriented Design against Briand's Property", IJIEEB, vol. 6, no. 3, pp. 28-33, DOI: 10.5815/ijieeb.2014.03.05

[9] The United Nations. (1948). Universal Declaration of Human Rights, pp. art. 21.3.

[10] The United Nations General Assembly (1966), International Covenant on Civil and Political Rights, Treaty Series, 999, 171.

[11] The United Nations (1966), International Convention on the Elimination of All Forms of Racial Discrimination. Treaty Series, 660, 195.

[12] Council of Europe (1950), Convention for the Protection of Human Rights and Fundamental Freedoms. In Council of Europe Treaty Series 005

[13] Charter on a Distinctive Partnership between the North Atlantic Treaty Organization and Ukraine (1997), available at: http://zakon4.rada.gov.ua/laws/show/ 994_002

[14] NATO-Ukraine Action Plan, adopted by the NATO-Ukraine Commission in 2002, available at: http:// www.nato.int/docu/basictxt/b030324u.pdf

[15] NATO-Ukraine Annual Target Plan (2004), available at: http://eu.prostir.ua/ library/610.html

[16] NATO-Ukraine Annual Target Plan (2008), available at: www.president.gov.ua/documents/7673.html

[17] NATO-Ukraine Annual Target Plan (2009), available at: http:// zakon2.rada.gov.ua/laws/show/116/2009

[18] Thomas, B. Mayfield, T. McCaskey, K. Weece, J. Matei, F.C. (2013), "Civil-Military Relations in Muslim Countries: The Cases of Egypt, Pakistan, and Turkey" Journal of Defense Resources Management, vol. 4, no. 2, Regional Department of Defense Resources Management Studies (DRESMARA) of Brasov, Romania, pp. 5-36. 
[19] Huntington, S. (1956), "Civilian Control and the Constitution", The American Political Science Review, vol. 50, no. 3 (Sep.), Cambridge University Press, pp. 676-699.

[20] Document of the Copenhagen Meeting of the Conference on the Human Dimension of the Conference on Security and Cooperation in Europe (1990), available

at: http://195.230.157.14/kb/article.phpid=17

[21] EU Action plan on justice and home affairs in Ukraine (Text approved by the Council on 10 December 2001), available at: http://zakon.rada. gov.ua/cgibin/laws/ main.cgi

[22] EU Action plan on justice and home affairs in Ukraine (2003), available at: http://ukraineeu.old.mfa.gov.ua/mediafiles/files/plan18062007. pdf

[23] EU Action plan on justice and home affairs in Ukraine (2005) EU Action plan on justice and home affairs in Ukraine (2005), available at: http:/ /zakon.rada.gov.ua/cgibin/laws/main.cgi

[24] EU-Ukraine Association Agenda to prepare and facilitate the implementation of the Association
Agreement (2009), available at: http:// zakon3.rada.gov.ua/laws/show/994_990

[25] Legislation of Ukraine (2003), Law of Ukraine "On democratic civilian control over Military organization and law enforcement agencies" from 19.06.2003 № 975-IV, available at: https://zakon.rada.gov.ua/go/975-15

[26] Legislation of Ukraine (2011), Law of Ukraine "On Access to Public Information" from 13.01.2011 № 2939-VI, available at: https://zakon.rada.gov.ua/laws/show/2939-17.

[27] Ministry of Defence of Ukraine (2020), Request reports, available at: https://www.mil.gov.ua/dostup-do-publichnoiinformaczii/zviti.

[28] Legislation of Ukraine (2018), Law of Ukraine "On National Security of Ukraine" from 21.06.2018 № 2469-VIII, available at: https://zakon.rada.gov.ua/laws/show/246919\#Text 